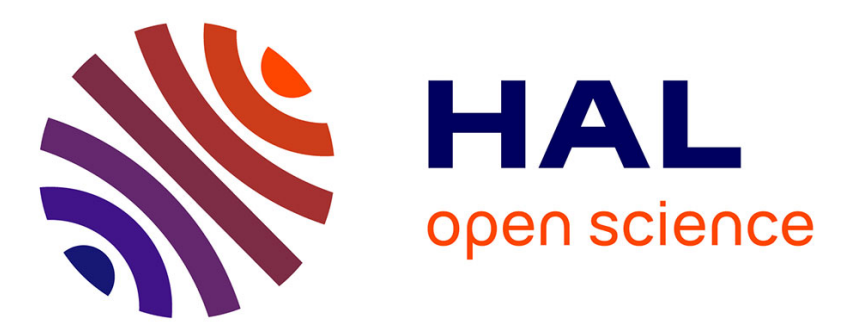

\title{
The machine body metaphor: From science and technology to physical education and sport, in France (1825-1935) \\ J Gleyse
}

\section{- To cite this version:}

J Gleyse. The machine body metaphor: From science and technology to physical education and sport, in France (1825-1935). Scandinavian Journal of Medicine and Science in Sports, 2013, 23 (6), pp.758-765. 10.1111/j.1600-0838.2012.01447.x . hal-01334341

\section{HAL Id: hal-01334341 \\ https://hal.science/hal-01334341}

Submitted on 20 Jun 2016

HAL is a multi-disciplinary open access archive for the deposit and dissemination of scientific research documents, whether they are published or not. The documents may come from teaching and research institutions in France or abroad, or from public or private research centers.
L'archive ouverte pluridisciplinaire HAL, est destinée au dépôt et à la diffusion de documents scientifiques de niveau recherche, publiés ou non, émanant des établissements d'enseignement et de recherche français ou étrangers, des laboratoires publics ou privés. 


\title{
The machine body metaphor: From science and technology to physical education and sport, in France (1825-1935)
}

\author{
J. Gleyse \\ STAPS, IUFM University of Montpellier 2, Montpellier Cedex 5, France \\ Corresponding author: Jacques Gleyse, Pr PhD, IUFM, Université de Montpellier II, Equipe Interdisciplinary Laboratory in \\ Didactics, Education and Formation, E.A. 3749., J.E. 2156, ED 60 Université Paul Valéry, 2 place Marcel Godechot, BP 4152, \\ F34092 Montpellier cedex 5, France. Tel: +33 467708187, Fax: 33 467618300, E-mail: jacques.gleyse@orange.fr
}

Accepted for publication 14 January 2012

\begin{abstract}
The long history of the conception of physical exercise in France may be viewed as a function of a series of changes in understanding the body. Scientific concepts were used to present the body in official texts by authors specializing in the subject, or to describe them, as did Michel Foucault, as epistemic ${ }^{1}$ changes. A departure occurred during the 19th century that is clearly demonstrated in the writings of Gustave Adolphe Hirn. This breakthrough concerned the idea of considering the organism as an energy-generating machine. This metaphor was employed in describing the body during physical exercise from the 17 th to the 19th centuries, when the body was thought of
\end{abstract}

as mechanical ${ }^{2}$. Such metaphors were used by the most relevant figures writing at the end of the 19th century in the rationale that is examined in this paper. It shows how Hirn, Marey, Lagrange, Demenij, Hebert, and Tissié saw the body and how they employed machine metaphors when referring to it. These machine metaphors are analyzed from the time of their scientific and technological origins up to their current use in physical and sports education. This analysis will contribute to the understanding of how a scientific metaphor comes to be in common use and may lead to particular exercise practices.
The purpose of this paper is to analyze how the bodymachine metaphor was used from the beginning of the 19 th century up to the 1930 s. The analysis concerns primarily the development in France and demonstrates the impact of the field of thermodynamic science (Sadie Carnot) and perhaps even technology (Denis Papin and James Watt) on biology then physical exercise. It also shows how the metaphor from mechanical models gradually affected the sphere of physical exercise; in other words, a development from applied science to physical exercise. The study is based on historical analyses of a body of work and articles available in the archives of the Montpellier Medical School and the National Library of France. These sources contributed significantly to the development of knowledge on the body and on exercise both nationally and internationally.

${ }^{1}$ Epistemic: a network, or a set of provisions for manifestations of the culture, comprising, in relation to that culture, knowledge that has to be revealed and is discovered through the sciences and philosophy. These discursive regularities, layers of constituted and historical knowledge, underlie the rules limiting what may or may not be thought, said, or seen during a certain period. This grid of knowledge determines practices and covers different forms of empirical knowledge. For Foucault, there have been three major epistemic changes: the Renaissance (16th century); the Classical Age (17th century); and the Modern Era (19th century), Les Mots et les Choses, 1966 [The Order of Things] (Foucault, 1969). Each transition corresponds to changes in manifestation and also, more importantly, to changes in knowledge and the sciences.
The study unearths items within texts, and some forgotten authors, that contributed to the dissemination of new conceptions of the body and physical exercise at the turn of the 19th and 20th centuries.

Much research has examined concepts concerning the body and machine metaphors. The first paper by Pierre Parlebas, "Sports dissipation," which appeared in the review Culture Technique (Parlebas, 1985) is an example. In France, in the field of the history of medicine, Georges Canguilhem wrote a paper much earlier entitled Machine et organisme (Machine and organism, Canguilhem, 1952), which showed how the body can be compared with a machine and vice versa, and how machines might be seen as the Ersatz of body functions. This thesis was also defended by Jurgen Habemas in Technik und Wissenschaft als Ideologie (1979) (Techniques and science as ideologies).

J. Gleyse has published two books that touch on the subject of machine metaphors: Archeologie de l'Education physique en France (The Archaeology of Physical Education in France, Gleyse, 1995) and L'Instrumentalisation du corps (The Instrumentalization of the Body, Gleyse, 1997). These two books, particularly the latter, show how ideas changed from the con-

${ }^{2}$ In the sense of the word used by Galileo. 


\section{Gleyse}

ception of the body founded on the acceptance of divine creation, or creation by nature "rerum opifex naturae" said Vesalius, to the idea of production by human hands "manus opera" or hand working, to quote Vesalius again. Once this way of representing the body became available as a possibility at the end of the 15th century and beginning of the 16th, a large number of concepts and discursive forms were employed, opening the door to the analysis of the mechanical body ${ }^{3}$ and the machine body $^{4}$, as a motor, a steam engine, or a combustion engine, drawing on models from the current technical field. While the works of Vesalius and other 16th century authors, including physicians from Montpellier in France: du Choul, Joubert, du Faur, de Monteux de Merybel, as well as Estienne in Paris, and even the surgeon to François I, Ambroise Paré, used metaphors drawn from crafts, nature, and sometimes from the weaponry of the period ${ }^{5}$. By the end of the 17 th century, the body was increasingly known as mechanical with a system of levers - first, second, and third order - being applied to it, as is apparent in Galileo's drawings of the new scientific method ${ }^{6}$. The trail can be followed through 18th and 19th century medical dictionaries such as the Panckouke Medical Sciences Dictionary and practical manuals on gymnastics from the same period, in the works of Frederico Amoros y Ondeano (founder of French military gymnastics) and Pier Heinrich Clias (nonmilitary gymnastics). Today, biomechanical work is continuing and enlarging the scope of this research.

Finally, in 1824, with the theories developed by Sadie Carnot on thermodynamics, another change occurred whereby the body was considered an energy producer and transformer and compared with mechanical energy and thermal energy. It is with these ideas and episteme that we linger a while in the following.

However, it must be said that all the points of view that contributed historically to adopting these scientific and technological concepts of the body and body techniques are still identifiable today like superposed archaeological layers. For example, prior to the form of Swedish gymnastics mentioned in the writings of Pier Heinrich Ling in the early 20th century, the "mechanical body" strata is still found in physical fitness centers with stretching and keep fit exercises. The "energy strata," which is also further examined below, is still largely present in most endurance sports, such as road cycling, 1500-m swimming, $10000-\mathrm{m}$ running, marathon races, as well as resistance sports, concentrating less on stamina, like 400

\footnotetext{
${ }^{3}$ The body as lever, pulley, and moment of force.

${ }^{4}$ The body as a motor, steam engine, or combustion engine.

${ }^{5}$ The hinged body, oyster shell, crossbow ratchet, firing pin, bow, and arrow.

${ }^{6}$ The machine metaphors used during the same period should also be mentioned: Descartes' "robot" body, mentioned particularly in $D e$ Homine figuris, which was published after his death in 1664, and more obviously Méditations métaphysiques and in the subsequent period the work of Claude Bernard, although the latter are less directly related to machine metaphors.

${ }^{7}$ From the scientific work of Borelli, 1686.
}

to 1500 meters flat racing, aerobics, and step exercises. The tests designed by Astrand and Rhyming (1954) and Léger and Boucher (1980) are frequently used in France in Physical and Sports Education for measuring aerobic strength, and even in some cases maximum aerobic speed $\left(\max \mathrm{VO}^{2}\right)$. The theory of $\max \mathrm{VO}^{2}$ is largely derived from the bioenergetic theories explained by Gustave Adolphe Hirn in the mid 19th century and then taken up by Marey, Lagrange, Demenij, and finally Hebert, at approximately the same time.

\section{Coal and oxygen at the start of the 19th century}

Quite clearly, the industrial revolution, first in Great Britain and shortly thereafter in France, was based on coal and initially on the steam engine and had the effect of refining the theories on both of them.

In 1707, Denis Papin made a machine producing about 8.65 horsepower, the equivalent of the power of at least 50 men. It is easy to understand what such power might have meant at that time, creating myths and models and metaphors of what constitutes the body. While it may be difficult to relate to this metaphor today, a parallel can be drawn with the power of the cyber world and information technology. Then, in 1712, Thomas Newcomen invented the first really serviceable, versatile steam engine, although it was actually no more powerful than the one designed earlier by Denis Papin.

James Watt (1736-1819) was certainly one of the first theoreticians on this subject. Watt developed the notion of horsepower and considerably improved the operation of machines. It was Sadie Carnot in 1824, however, who put forward the idea of equating mechanical energy and calorific energy on which all thermodynamic theories were later founded.

Much earlier, many authors were already applying these concepts and metaphor to the body. This was hardly surprising as Jean Claude Adrien Helvetius (1685$1755)^{8}$, the father of the first "Fermier général" or farm tax collector and better known as a materialist philosopher, had already considered the cause of red blood and black pulmonary blood. Long before the idea that organic combustion caused blood to be red was even raised at all, he examined the question in his book Idée générale de l'œeconomie animale fondée sur des expériences précises et quelques observations sur la petite verole (The general idea of animal economics founded on several precise experiments and observations on small pox) (1752). This concept has been attributed erroneously to Antoine Laurent de Lavoisier, Laplace, and several others.

\footnotetext{
${ }^{8}$ Pages 15 and 16 of the work very clearly and precisely explain the reasons for red blood and black blood. Jean-Claude Adrien Helvetius developed the following idea on this subject: "Certain solutions with different characteristics do not mix or touch without starting to ferment. Blood, which is comprised of various solutions, includes many that are able to ferment when they come in contact with one another [. . . ] Several 'Phisiciens' $\{$ sic $\}$ have tried in vain to deny this fact." (Helvetius, 1752, p. 13).
} 
In the industrial environment in which mines and the steam engine were to predominate, described a few years later by Guy de Maupassant (1883) and Emile Zola (Germinal, 1885), it is hardly surprising that the subject of coal, carbon, and bodily combustion were to become prevalent.

Towards the second half of the 19th century, coal and steel were in industrial use everywhere. They invaded factories. They were the industrial society's symbol of progress and of the alienation of underground miners: "A hundred giant chimneys vomit snakes of smoke into the air, others less tall spit steamy breath; all of which mixes, spreads, floats, covers the town, fills the streets, hides the sky, puts out the sun [...] the smell of chimneys, tar and bitumen drifts in the air, contracting the throat, oppressing the chest, and sometimes too an acrid smell of iron, smithy, burning metal, a blazing hell prevents breathing" (Maupassant, 1883, p. 34).

The ninth edition of the work of Chevalier Richerand, professor of physiology, Nouveaux elemens de physiologie (Richerand, 1825) (New Issues in physiology), argued the hypothesis of organic combustion and carbon matter quite clearly: "Among the hypotheses put forward to express the phenomenon of muscular contraction, that which advocates the responsibility of combinations of hydrogen, carbon, nitrogen and other combustible substances found in the thick body muscle with oxygen [misspelt in French] that carries blood to the arteries, is not improbable" (Richerand, 1825, p. 249).

Some 30 years later, this position was also endorsed by De Brewer in a layman's book intended for training primary school teachers at the Ecoles Normales, not as a working hypothesis but as a fact: "What is the cause of animal heat? Animal heat arises firstly from blood circulation, and secondly from combustion of hydrogen and carbon in the lungs and capillary vessels" (De Brewer, 1858, p. 470).

In the mid 19th century, the metaphor of man-engine, man being no longer thought of as animated by God but rather as the birth of energy, was more than ready to be taken into the domain of science and to transform ideas on physical exercise.

\section{The revolution of the man-machine metaphor in physical exercise}

In the mid-19th century, Gustave Adolphe Hirn (1815-1890) in his Conséquences philosophiques et métaphysiques de la thermodynamique (Philosophical implications of the theory of thermodynamics) stated authoritatively, and demonstrated as conclusive after conducting numerous experiments on his domestic help, that: "From the weight of carbonic acid found in the air exhaled, the weight of the carbon burnt is calculated; the weight of oxygen in this carbonic acid is added to that which the air lacked; this shortage enabling the quantity of oxygen burned to be measured" (Hirn, 1868, p. 80).
Hirn drew the conclusion that "there is [. . .] a mechanical equivalent to work, and a calorific equivalent to heat" (Hirn, 1868). From this demonstration, the metaphors of the animal-machine and the man-engine were to be used by many other authors and by Hirn himself: "What has just been stated in terms of the engines in the physical world, obviously and literally applies to organised engines and [...] to man-engine, which is easier to examine" (Hirn, 1887, p. 678). This analysis enabled him, moreover, to declare that the human-engine is as efficient as the mechanical engine and vice versa: "As an engineer, I conclude therefore that the human engine yields only twelve per cent [of the energy consumed]. Our steam engines today yield as much: the work of man, you see, supports the parallel with the living engine. A steam engine that supplies the work of a horse of average strength, weighs ten times more than the live engine" (Hirn, 1868, p. 45). Hirn, by contrast with Lavoisier who nevertheless suggested a view as original as that expressed by Vesalius in 1543, by Copernicus on the macrocosm or by Galileo on rotating planets, is ignored by most reference books including encyclopedias and encyclopedic dictionaries. It was, however, Hirn who enabled us to think of the body as being thermodynamic and, finally, it was he who applied rules for the yield from steam engines and thermal engines. In this respect, Hirn was one of the most important figures to contribute to the determining calculations for sports performance. There is much research ${ }^{9}$ that subsequently applied these theories to physical exercise and more specifically to physical education.

Following Hirn, but more widely read and appreciated, is the spiritual godfather of Georges Demenij, Etienne-Jules Marey (1830-1904), a renowned professor at the College of France. Marey published the work cited by generations of physical education students in France: La Machine animale. Locomotion terrestre et aerienne (Marey, 1873) (The animal-machine. Air and land locomotion). The message expressed in this paper could not be more explicit: Man, an animal, is also a machine. The implications of this statement on work and physical exercise must be explained: "Quite often, over various periods, we have compared the living being with the machine but it is only now, in our own time that we understand the accuracy of this comparison. [...] comparing animals with machines is not only legitimate, it is also of great utility when expressing different points of view." (Marrey, 1973, p. V-VI).

Starting from this premise, the theories of EtienneJules Marey, with significant assistance from Georges Demenij at the laboratory of Parc des Princes, not only invented chronophotography for the purpose of understanding movement, but also to a certain degree prepared the way for the Lumière Brothers' invention: cinematography. Chronophotography provided a basis for

${ }^{9}$ Lagrange, Demenij. 


\section{Gleyse}

analyzing physical exercises, irrespective of what they comprise, focusing on the human being as a producer and transformer of energy. It also made a considerable contribution to the application of these theories in the industrial world. It was by employing this analogy that Frederic Winslow Taylor was able to construct, with Muybridge, the idea of scientific rationalization of work, whether in the factory, in the construction industry, or on the docks. The resultant method is known as Taylorism. As is shown in the following, this method is apparent too in physical education in France.

\section{Between energy and sport}

Fernand Lagrange (1846-1909), physician, athlete, and disseminator of the thermodynamic rationale of the human body, had a primary interest in science but discovered the industrial world of the 19th century in Taylor's discourse.

Lagrange presented his medical thesis in 1869, after which he devoted his time to athletics and conducting research into the physiology of the body. For this, he travelled widely in Europe studying the methods then in use. The conclusion he reached from his odyssey was that the gymnastic exercises, which were developed from the strict Swedish model had little value. In his view, what was really important was that exercise was viewed as appealing to its practitioners. He focused therefore on games, fresh air, and sports, which he viewed as teenage games. Based on a bioenergetic conception of the body, he rejected physical activities that were too tiring.

In 1892, he was involved, as were Etienne-Jules Marey and Georges Demenij, in the Commission for reforming physical education in France. He contributed to the Manuel d'Exercices Physiques et de jeux scolaires (Manual of Physical Exercises and School Games), which appeared in 1907 . He stated many times that man is an animated engine: "The human body has been compared, as a source of energy, to a machine running on heat. We know that no machine creates power. The most perfect engine can only turn heat into movement" (Lagrange, 1888, p. 28).

Lagrange published several papers with the founder of the modern Olympic Movement, Baron Pierre Frédy de Coubertin (1863-1937) and Georges de Saint-Clair. His publications appeared in La Revue Athlétique primarily in 1890, particularly on the subject of adolescence. He took part in the Committee for the Propagation of Physical Exercise, which in a way was the predecessor of the sports federations and the Union des Société Françaises de Sports Athlétiques, chaired by Jules Simon (Minister for Thiers) and inaugurated in June 1888, particularly through the initiative of the Baron. Lagrange was involved with others in the development of the sports movement in France. Although hostile to competitive sports, authors like Demenij and later Georges Hebert, quoted the leading article he published in 1888: Physiologie des exercices du corps (Physiology of Bodily Exercises). For this work, Fernand Lagrange was awarded the prestigious Vernois Prize by the French National Academy of Medicine and Sciences. A report by the Academy stated moreover that "Dr F. Lagrange has written an excellent treatise on the physiology of bodily exercises and the dual aspects of science and practical exercises. As gymnastics have returned to favour in our schools, the Academy is aware of this advance [...], the author will receive the sum of 250 francs" (report dated 16 December 1890).

It is paradoxical that this key figure took part, not only in the Jules Simon Committee, but also in its well-known institutional rival: the Ligue Nationale d'Education Physique, which became the Ligue Française d'Education Physique, founded in October 1888 on the initiative of Paschal Grousset (1844-1909), alias Philippe Daryl, alias Andre Laurie, and Jules Verne's ghost writer. In the same year as publishing Physiologie des exercices $d u$ corps, Lagrange published La Renaissance physique (The physical Renaissance), a radical critique of English sports, particularly addressing Baron de Coubertin and his L'Education en Angleterre (Education in England) and L'Education Anglaise en France (English Education in France).

Fernand Lagrange was definitely of crucial importance since, for him, a little like for Georges Hebert, although the latter disparaged sport for its lack of moral values, any exercise is good exercise when it involves the energy process. This was especially the case when it meant not leaving children and young people at their desks all day in airless rooms and establishments.

Lagrange also explicitly asserted that: "Let fencing, gymnastics with apparatus or haute école equitation be prescribed for all those idle minds whose brains languish for want of action. [. . .] but to the child overloaded with book work, long walks should be prescribed, easilylearned rowing exercises and if there is nothing better, the old French game of leap-frog, parallel bars, chases, races, anything other than overcomplicated exercises and acrobatic gymnastics ..." (Lagrange, 1888, p. 363). Lagrange and Paschal Grousset were brought together by their interest in games, and an interest in sport drew Lagrange to Baron de Coubertin.

The plan for the work Physiologie des exercices $d u$ corps, as well as the chronological sequence of articles that appeared in Revue Scientifique, and Le Gymnaste, throw light on the focus of Fernand Lagrange's interests. In the foreword to Physiologie ... he defines his methodological framework: "The best way for everyone to use this precious nutrition modifier remains to be determined, just as specifying the role of exercise in relation to age, sex, temperament, and the various conditions of social life; in a word, establishing the rules and formulating the methods for the rational application of muscular exercise, depending on the situation and the subject 
[...] since only physiology can provide us with the first notions on which the hygienist depends" (Lagrange, 1888, p. V).

From this methodological basis, the book turns to the subject of muscular workout. It provides details of the mechanics and movements of organs. Lagrange then asks two critical questions that are central to the whole work, one concerning heat and the other concerning combustion. At this point, he cites and explains the theories of Marey and Hirn, Marey being explicitly quoted. The second part of the treatise is on bioenergy and fatigue, the third on becoming accustomed to work, and the fourth on various forms of exercise. It can be seen at this point that exercises were classified, as occurred during the Renaissance, as gentle, moderate, and violent and not as a function of mechanical theory as being easy or difficult to accomplish. In this chapter, the sophists of gymnastics and gymnastique savante ${ }^{10}$ are rejected. Lagrange prefers children's games. Clearly, he favors exercises that produce energy over those that are complicated. He stresses the value of an energetic, tiring game (within reasonable limits) by comparison with a difficult gymnastic exercise that does not mobilize the human engine, the animal-machine. This point enables him to emphasize the value of athletics, running, and rowing and basic exercises more generally. Lagrange was among the first to suggest dividing or segmenting work and to say that moderate effort over a protracted period is the most beneficial. He finally laid the ground for the French method, similar to Romero Brest, who founded a national method in Argentina, and that Georges Demenij was to expand upon a little later.

Lagrange's book concludes by discussing two central issues on the subject of mobilizing energy: firstly, the results of exercise and secondly the brain's role in exercise. The latter point, moreover, virtually led the work of Lagrange to fall into the arena of psychomotricity.

Certainly, for Lagrange, the most positive exercise is that which produces muscular fatigue without causing nervous fatigue. In this respect, he prepared the basis for Georges Hebert's natural method fostering the development of stamina rather than the use of difficult gestures, and included amusing physical education routines which might, for older participants, sometimes seem more like sport.

In any event, it was because Lagrange built his method on the machine metaphor that he was able to renounce gymnastique savante, which was based on the mechanical metaphor. Other writers also valued this bioenergetic, body-machine view, despite not necessarily drawing all the practical conclusions from it they might have done. During this same period, only Paschal Grousset attached as much importance to traditional French games, but for him their basis was not physiological: it was political. In

\footnotetext{
${ }^{10}$ Gymnastique savante refers to an exercise routine that is deemed to challenge or tone up if not all, then a major part, of the body's muscular system.
}

his view, the game was the physical activity of ordinary people and not that of the aristocracy which he abhorred. But Grousset was not a doctor; he was a politician who became Minister of Foreign Affairs for the Paris Commune at the age of 27, which subsequently led to his deportation to New Caledonia. Grousset continued to maintain the view that sport is an upper class activity with no virtue for the masses and the proletariat. In fact, he considered that the values inherent in sport were disastrous for equality and fraternity through providing an elitist model for exercise, a quality that he did not ascribe to traditional French games.

\section{Gymnastique savante and man-engine. Tissié (1852-1935) and Demenij (1850-1917)}

There is no point in recapitulating what was known in France as "the war of methods" at the start of the 20th century, when Baron de Coubertin, Georges Demenij, and Philippe Tissié were in disagreement. On the subject of values ("massism" vs elitism), Coubertin's opinions differed substantially from those held by Demenij and Tissié while the latter two held strong views on the scientific conception and value of exercise. Although their views on its physiological foundation were in fact very similar, they held radically different opinions regarding types of exercise. Demenij had studied chronophotography and concluded that complete, wellrounded, and continuous exercise was to be preferred. Tissié relied on his empirical knowledge of classical Swedish gymnastics and did not attempt to produce other, more energetic forms, although he too employed man-engine metaphors.

Demenij's views were close to those of Muybridge (1872-1885) and Taylor (1902) when he said:

Man, the manual labourer, has an active life that is longer than that of inanimate machines; for example, the most perfect steam engine will not continue to run for more than fifteen or twenty years without the need for repair [...] engines that come even remotely close to such mobile perfection are quite rare.

$$
\text { Demenij, 1890, p. } 670
$$

It can be seen that the steam engine metaphor is used here by the joint originator of chronophotography, just as it was by Lagrange, Marey, who was his spiritual guide and later his enemy, and Hirn. Demenij's comments are even more interesting as he was involved in training primary school teachers in Paris, being one of the originators and instructors of the Certificat d'Aptitude à l'Enseignement de la Gymnastique dégrée supérieur (Advanced Level Gymnastics Teaching Certificate). He was also very involved at the Ministry for Public Instruction of Fine Arts and Religions. After 1905, the reference to religion was discontinued. Demenij took part in the 


\section{Gleyse}

ministerial commissions that drafted the Manuel d'exercices gymnastiques et de jeux scolaires in 1891 (School Gymnastics Exercises and Games Manual). In 1907, he hand wrote the Manuel d'exercices physiques et de jeux scolaires. Conversely, he was excluded from drafting the Réglement d'Education Physique (Rules for Physical Education) in January 1910 and it was Philippe Tissié who did so; his conception of man-engine is found therefore in these texts. However, Demenij, an ardent supporter of Swedish gymnastics, which he was convinced had cured him of a possibly fatal illness, never fully renounced the forms of exercise it promoted. His "French Method" is a mixture of Swedish gymnastics, games, as little sport as possible and complete, wellrounded, and continuous movement, of which he largely approved, therefore being relatively energetic though still fairly close to the Swedish model.

Swedish ideas on asceticism seemed important to Demenij and, by contrast with Lagrange, he considered that exercise is beneficial as a function of work and not of pleasure. In other words, he did not draw all the conclusions possible from his thermodynamic premises. However, like Lagrange he thought that: "The human body can be likened to a machine: we require it to work in high yield conditions" (Demenij, 1905, p. 73). As has been demonstrated elsewhere (Gleyse, 1999), Demenij's views were very close to those of F. W. Taylor regarding industrial production. Demenij attempted to establish the optimum conditions for using bodily energy in exercise, just as Taylor did for brick layers. However, the primary question actually concerned the energy dispensed by the "human machine," knowing that this issue was critical at the start of the 20th century since, by contrast with today, a high proportion of productive energy was still of animal origin.

Philippe Tissié, obtaining his doctorate in medicine in 1887, was even more strongly influenced by traditional bourgeois and mechanical forms of exercise. Although he published in the Revue des jeux scolaires from the 1890s, he mostly advocated the gestural Swedish form of exercise. The Lendits, which came into being in 1891, in part through his contribution, are Swedish gymnastic-type exercises that were performed by groups in the public squares and stadiums. Tissié differed violently from Demenij. Their quarrel was considered science-based, since Demenij reproached Tissié with relying on mechanical and not energy-based exercises. Yet, strangely, Tissié's assertions did not contradict those of Demenij and showed him to be close to Taylorism: "Effort training must be pursued by the people's leaders [...] the merest physical exercise has more commercial value from the point of view of developing human capital than, for example, erudite hair-splitting over spelling" (Tissié, 1919, p. 234). Even more clearly, he stated that: "Physical Education should be envisaged for the value of the advantages in energy it would bring to the nation" (Tissié, 1919, p. 241). He seems, furthermore, to clearly adopt the view of man-engine initiated by Hirn: "The human engine is productive. The employee is the owner and employer of his animal-machine. For him, it constitutes his primary capital; his primary source of income [...] this machine exists in the presence of the employer's industrial machine, whether in competition or in harmony with it" (Tissié, 1919, p. 241). However, despite the fact that Tissié advocated cycling or races on foot in the Ligue Girondine d'Education Physique (The Gironde League for Physical Education), his assignment in Sweden between 1898 and 1905 convinced him of the suitability of the Swedish method for physical education in schools. His prodigious, voluntary classes at the Ecole Normale de Jeunes Filles de Pau (Young Women's Teacher Training College in Pau, France) from 1903 to 1914 supported the argument that the Swedish method should be used in primary schools, an argument substantiated through the positive results he achieved and the fulsome praise he received from the head of the college. Finally, despite all his views of the mechanical body and his ideas on man-engine, he said:

"It has been claimed that Swedish gymnastics is boring. Let us be frank. Every school subject is uninteresting or tedious depending on the taste and ability of the pupil, and it is particularly the manner in which a subject is taught that determines how disciplines are judged. The same applies to gymnastics" (Tissié, 1905, p. 12).

\section{The last uses of the man-engine metaphor}

After World War II, the view of man-engine gradually disappeared from the world of Sports and Physical Education: Psychomotricity took its place. Yet, between the two world wars, there were many writers who still used the machine metaphor.

Dr. Boigey (Boigey, 1923), the physician at the Evian water therapy center, reinstituted the use of these metaphors in several papers. In France, the monument to physical education between the wars was the Traite d'Education physique (1930) (Treatise on Physical Education), published in two volumes of more than 600 pages each and written by a well-known eugenicist, Prof. Marcel Labbé, who published several papers using manmachine and man-engine metaphors. But the best-known author in France and the one most respected at the time, after the Physical Education Congress in 1913 and the Battle of the Marne, was the French naval commander, Georges Hebert (1875-1957), acolyte of the natural method, who certainly paid the greatest attention to the energetic form and the human machine by advocating the idea of "capital" and stamina over any other view of exercise. Although his method was built on 10 types of exercise, "walking, running, jumping, climbing, lifting, throwing, carrying, quadrupedal movement, self-defence and swimming," he considered the essential was founded less on the form of exercise undertaken than on organic activity, the activity of the animal-machine. From this 
Body machine: from science to P.E. in France

standpoint, Hebert was very close to Fernand Lagrange. They were separated perhaps by the fact that Lagrange tolerated sport, accepted it even, whereas Hebert, just like Grousset, Demenij, and Tissié, very clearly considered it a "social scourge" viewing it as narcissistic, egocentric, and elitist. Yet, Hebert explicitly quoted Lagrange (something he did very seldom for any other author) when it was a matter of expressing the physiological basis of his method. Moreover, particularly in Le Sport contre l'Education physique (Hébert, 1925) (Sports vs Physical Education), he made use of motor vehicle metaphors, specifically regarding the organism's moral brakes, and used metaphors like "steamers" when discussing coal consumption and especially the advice not to push the "body machine" to extremes. Finally, he very frequently employed the idea of "capital" training. In other words, a concept founded on energy, providing the basis of L'Education physique virile and morale par la méthode naturelle (Hébert, 1936) (Virile and Morale Physical Education using Natural Methods).

In conclusion, this paper is limited to examining the use of machine metaphors in the realm of physical education in France from the end of the 19th to the first third of the 20th century. We see here how a concept of the body became established, which led to it no longer being viewed as a precise instrument comprising moments of force, mechanics, levers, and pulleys but much more as a heat-producing engine. This development was to encourage the birth of a representation of the body inspired by Taylorism and sports. In fact, this led to the development of records of physical achievement and, as a corollary, the idea of champions. When the body is considered a human-engine, priority is given to ensuring the best energy yield. Thus, although sport is not yet the focal point in physical education in France, the man-engine metaphor has allowed the premise to become established and to obtain a more important place than other forms of exercise. In fact, it is actually when the body is viewed in terms of energy and not of precision or strength that the issue of its potential for yield and performance can be considered. Even though, in contrast to Lagrange, Tissié and Demenij refused, for different reasons, to draw all the conclusions possible from the machine-body metaphor, they nevertheless subscribed to this rationale. With his paper Les Bases scientifiques de l'Education physique (1902) (The Scientific Bases of Physical Education), Georges Demenij can perhaps be considered by the world of physical labor as comparable with Frederic Winslow Taylor, who published Scientific Management in the same year (see Gleyse, Bui-Xuân \& Pigeassou, 1999).

In any event, the view of the body established here still exists today in terms of archaeological strata, although by the early 1960s it was no longer a central feature in physical education terminology in France. The body is now seen as a micropower or biopower ${ }^{11}$ providing for the establishment of another system of control in physical education: that of competitive sport as opposed to sporting games. Since the acceptance of competitive sport has a definite place in French social history, credit is certainly due to Lagrange for his prescience.

\section{Perspectives}

There is little doubt that machine metaphors used in relation to the body and physical exercise are tools that enable the general public to better understand complex physical concepts that would otherwise be difficult to explain. At the same time, it can be seen that these metaphors belong to an epistemic, socioeconomic frame of reference and perhaps even to a productive or laboring schema. In this sense, they can be viewed as quasiscientific. This paper also demonstrates how some metaphors are historically and socioculturally more successful than others and explains their comparatively rapid obsolescence. Furthermore, it might contribute to showing something of the porosity of a scientific or technological field and the fecundity of a multidisciplinary approach covering life sciences, physical sciences, natural sciences, and perhaps human sciences, too. The study provides an insight into the migratory nature of scientific concepts.

Key words: exercise, body, mechanical, machine metaphors, bioenergetic.

${ }^{11}$ See Foucault, 1975.

\section{References}

Amoros y Ondeano M. Manuel d'éducation physique. Gymnastique et morale. Paris: Roret, 1834.

Astrand PO, Rhyming I. A nomogram for calculation of aerobic capacity (physicalfitness) from pulse rate during submaximal work. J Appl Physiol 1954: 7: 218-221.

Boigey M, ed. Traité scientifique d'Education physique. Paris: Masson, 1923.
Borelli JA. De motionibus naturalibus. Lugduni Batav: Apud Petrum Leffen \& Franciscum Moyardum, 1686.

De Brewer F. La clef de la science ou les phénomènes de tous les jours. Paris: J Renouard, 1858.

Canguilhem G. La connaissance de la vie. Paris: Vrin, 1952.

Carnot S. Réflexions sur la puissance motrice du feu. Paris: Blanchard, 1824.

Cebe D, Lecoq G, Gleyse J, eds. L'Education physique au xxe siècle de ses environnements à l'élève. Paris: Vigot, 2004.

Clias PH. Gymnastique élémentaire ou cours analytiuqe et gradué d'exercices propres à développer et à fortifier l'organisation humaine. Paris: N L Colas, Locard et Davi, 1819.

Copernicus N. De revolutionibus orbium cœlestium. Norimbergae: I Petreium, 1543.

Daryl P. (alias P Grousset) La Renaissance physique. Paris: Hetzel, 1888. 


\section{Gleyse}

Demenij G. Effets physiologiques et philosophiques de la gymnastique rationnelle. Paris: Neuilly-Bouzin, 1880.

Demenij G, ed. Education et harmonie des mouvements (science et art du mouvement). Paris: Fournier, 1885.

Demenij G. De la précision des méthodes d'éducation physique. Revue Scientifique, (Revue Rose), Tome XLVI, Paris, Sept. 1890: 12: 354-359.

Demenij G. Plan d'un enseignement supérieur de l'éducation physique. Paris: Alcan, 1892a.

Demenij G. L'éducation physique en Suède. Paris: Ed. Scientifiques, 1892b.

Demenij G. Les bases scientifiques de l'éducation physique. Paris: Alcan, 1902, rééd. 1926.

Demenij G. Mécanisme et éducation des mouvements. Paris: Alcan, 1903, rééd. 1924.

Demenij G. Sur l'évolution de l'éducation physique en France. Revue Scientifique, (Revue Rose), Tome IV, Paris 1905: 13: 394-398.

Demenij G. Evolution de l'éducation physique: l'Ecole française. Paris: Fournier, 1909.

Demenij G. L'éducation de l'effort. Paris: Alcan, 1914.

Demenij G. L'éducation physique des adolescents. Paris: Alcan, 1917.

Demenij G. Pédagogie générale et mécanisme des mouvements. Paris: P.U.F., 1922.

Descartes R. De homine figuris. Lugduni Batavorum: Hackania, 1664.

Dickenson HW. James Watt: Craftsman and Engineer. Cambridge: University Press, 1935.

During B. La crise des pédagogies corporelles. Paris: Scarabée, 1981.

During B. Des jeux aux sports. Paris: Vigot, 1984.

During B, Demenÿ G. La première tentative d'une éducation physique scientifique. In: Zoro J (dir.) Images de 150 ans d'e.P.S. Paris: A.E.E.P.S., 1986: 36-41.

Estienne C. De dissectione partium humani coporis. Parisii (Paris): Simon Colinae, 1545, Eb 67 in $\mathrm{f}^{\circ}$.

Foucault M. Les Mots et les choses. Paris: Gallimard, 1969.

Foucault M. Surveiller et punir. Paris: Gallimard, 1975.

Galilée G. Dialogo sopra i due massimi sistemi del mondo. Fiorenza: G B Landini, 1632.

Gleyse J. Archéologie de l'Education Physique a xxe siècle en France. Paris: PUF, 1995.

Gleyse J. L'Instrumentalisation du corps. Une archéologie de la rationalisation instrumentale du corps de l'Age classique à la période hypermoderne. Paris: L'harmattan, 1997.

Gleyse J. L'Education physique au XXe siècle: approches historiques et culturelles. Paris: Vigot, 1999.

Gleyse J, Bui-Xuân G, Pigeassou C. Taylor et Demenÿ. Etude comparée de deux discours de la deuxième révolution industrielle. Sport History Review, Toronto 1999: 30 (2): 168-186.

Habemas J. Technik und Wissenschaft als "ideologies". La Technique et la science comme "idéologies". Paris: seuil, 1979.

Hébert G. Guide d'Education physique. Paris: Vuibert, 1909.

Hébert G. Le Sport contre l'éducation physique. Paris: Vuibert, 1925.

Hébert G. L'Education physique virile et morale par la méthode naturelle, Vol. I. Paris: Vuibert, 1936.

Helvetius JC. Idée générale de l'œconomie animale et observations sur la petite vérole. Paris: Rigaud, 1722.

Hirn GA. Théorie mécanique de la chaleur. Paris: Lieber, 1862.

Hirn GA. Exposition analytique et expérimentale de la théorie de la chaleur. Paris: Mallet Bachelet, 1863.

Hirn GA. Conséquences philosophiques et métaphysiques de la thermodynamique. Paris: Gauthier-Villars, 1868

Hirn GA. La thermodynamique et le travail chez les être vivants. Revue scientifique, Paris, Bureau des revues, May 1887: 22: 673-684.

Labbé M. Energétique musculaire. In: Labbé M, ed. Traité d'éducation physique, t. I. Paris: Doin et Cie, 1930a: 292-300.

Labbé M. Traité d'E.P., Vols I \& II, Paris: Doin, $1930 b$.

Lagrange F. L'éducation physique des jeunes enfants. Revue Scientifique, (Revue Rose), Tome XVI, Paris 1888: 33: 632-638.

Lagrange F. La fatigue et l'entraînement. Revue Scientifique, (Revue Rose), Tome XV, Paris, Janvier 1888a: 34: 203-211.

Lagrange F. Physiologie des exercices du corps. Paris: Félix Alcan, 1888b.

Lagrange F. La gymnastique athlétique. Revue Scientifique, (Revue Rose), Volume XIX, Paris, January 1890a: 11: 113-115.

Lagrange F. L'hygiène de l'exercice chez les enfants et les jeunes gens. Paris: Alcan, 1890b.

Laplace PS. Exposition du système du monde. Paris: Crapelet, An VIII, 1800.

Lavoisier AL. Traité élémentaire de chimie, présenté dans un ordre nouveau et d'après les découvertes modernes. Paris: Cuchet, 1793.
Léger L, Boucher R. An indirect continuous running multistage field test: the Université de Montréal Track Test. Can J Appl Spt Sci 1980: 5 (2): 77-84.

Ling PH. Gymnastikens allmänna Gründer. Uppsala: Palmblad and Comp., 1834.

Marey EJ. La machine animale. Locomotion terrestre et aérienne. Paris: Germer Baillères, 1873.

Marey EJ. Du moyen d'économiser le travail moteur de l'homme et des animaux. In: Ecole pratique des hautes études, ed. Physiologie expérimentale. Travaux du laboratoire de M. Marey, Année 1875. Paris: Masson, 1875: $1-18$.

Marey EJ. Ecole Pratique des Hautes Etudes. Physiologie expérimentale. Travaux du laboratoire de M. Marey, 4 volumes, 1875 to 1878 . Paris: Masson, 1875-1878.

Maupassant G (de). Au Creusot. In: Maupassant G, Gil Blas, eds. Paris: Victor Havard, 1883: 23-29.

Muybridge E. Animal locomotion. Philadelphia: University of Pennsylvania, 1872-1885.

Parlebas P. La dissipation sportive. Cult Tech 1985: 13: 35-47.

Richerand M. (Chevalier de) Nouveaux elemens de physiologie. T. 2. Paris: Béchet Jeune, 1825.

Taylor F. The principle of scientific management. New-York: Harper \& Brothers, 1902.

Thooris A. La forme humaine. In: Labbé M, ed. Traité d'Éducation physique, Vol. I \& II. Paris: Doin et Cie, 1930: 131-155.

Tissié P. Le guide du vélocipédiste. Paris: Doin, 1883.

Tissié P. Les aliénés voyageurs. Bordeaux: Thesis, 1887.

Tissié P. La fatigue et l'entraînement physique. Paris: Alcan, 1897.

Tissié P, ed. L'éducation physique au point de vue historique, scientifique, technique, critique, pratique et esthétique. Paris: Larousse, 1901.

Tissié P. L'évolution de l'éducation physique. Revue Scientifique, Vol III, Paris, Janvier 1905: 24: 744-750.

Tissié P. L'éducation physique et la race. Santé, travail, longévité. Paris: Flammarion, 1919.

Tissié P. Précis de gymnastique rationnelle de plain-pied et à mains libres, 1st edn. probably 1905, re-ed. Bordeaux: Bière, 1946.

Vesalius A. De humani corporis fabrica, 2nd edn. Basilae: J. Opérimus, 1555 (1st 1543).

Zola E. Germinal. Paris: Larousse, 1885. 